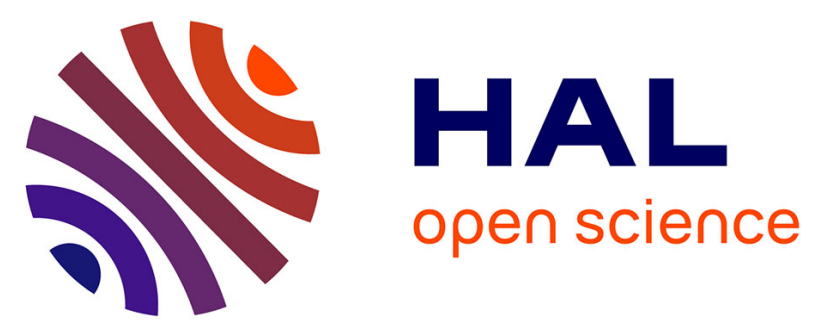

\title{
Renunciation of health care by people living with HIV in France is still associated with discrimination in health-care services and social insecurity - results from the ANRS-VESPA2 survey
}

Marion Fiorentino, Marie Suzan-Monti, Antoine Vilotitch, Luis Sagaon-Teyssier, Rosemary Dray-Spira, France Lert, Bruno Spire

\section{To cite this version:}

Marion Fiorentino, Marie Suzan-Monti, Antoine Vilotitch, Luis Sagaon-Teyssier, Rosemary DraySpira, et al.. Renunciation of health care by people living with HIV in France is still associated with discrimination in health-care services and social insecurity - results from the ANRS-VESPA2 survey. Antiviral Therapy, 2018, 23 (5), pp.443-450. 10.3851/IMP3220 . hal-02146906

\section{HAL Id: hal-02146906 \\ https://hal-amu.archives-ouvertes.fr/hal-02146906}

Submitted on 12 Jul 2019

HAL is a multi-disciplinary open access archive for the deposit and dissemination of scientific research documents, whether they are published or not. The documents may come from teaching and research institutions in France or abroad, or from public or private research centers.
L'archive ouverte pluridisciplinaire HAL, est destinée au dépôt et à la diffusion de documents scientifiques de niveau recherche, publiés ou non, émanant des établissements d'enseignement et de recherche français ou étrangers, des laboratoires publics ou privés. 


\title{
Renunciation of health care by people living with HIV in France is still associated with discrimination in health care services and social insecurity - results from the ANRS VESPA2 survey
}

Marion Fiorentino ${ }^{1,2 *}$, Marie Suzan-Monti, ${ }^{1,2}$, Antoine Vilotitch ${ }^{1,2}$, Luis SagaonTeyssier ${ }^{1,2}$, Rosemary Dray-Spira ${ }^{3,4}$, France Lert ${ }^{5}$, Bruno Spire ${ }^{1,2}$, the ANRSVESPA2 Study Group

\author{
${ }^{1}$ Aix Marseille Univ, INSERM, IRD, SESSTIM, Sciences Economiques \& Sociales de la Santé \& \\ Traitement de l'Information Médicale, Marseille, France \\ 2ORS PACA, Southeastern Health Regional Observatory, Marseille, France \\ IINSERM, UMR S1136, Pierre Louis Institute of Epidemiology and Public Health, Team Research in \\ Social Epidemiology, Paris, France \\ ${ }^{4}$ Sorbonne Universités, UPMC Univ Paris 06, UMR_S1136, Pierre Louis Institute of Epidemiology and \\ Public Health, Team Research in Social Epidemiology, Paris, France \\ ${ }^{5}$ Centre de recherche en épidémiologie et santé des populations, Inserm U1018, Villejuif, France \\ *Corresponding author e-mail: marion.fiorentino@inserm.fr
}

\section{Abstract}

Background: This study aimed to estimate the frequency of renunciation of healthcare among people living with HIV (PLHIV) in France, including healthcare unrelated to HIV, and to characterize associated socioeconomic and psychosocial risk factors.

Methods: The cross-sectional ANRS-VESPA2 survey was conducted on adult PLHIV attending French hospitals in 2011. Correlates of healthcare renunciation in the 12 months before the survey were assessed through logistic modelling.

Results: Among the 3020 PLHIV included in the sample, $17 \%$ declared healthcare renunciation during the preceding year and $42 \%$ had a high level of social insecurity. During the previous two years, $8 \%$ and $11 \%$, respectively, were discriminated against by medical staff and family. In multivariate analysis, positive associations were found between healthcare renunciation and a high level of social insecurity (aOR [95\% $\mathrm{Cl}] 3.44[2.54 ; 4.65], \quad \mathrm{p}<0.001)$, having children (1.52[1.10;2.10], $p=0.01)$, smoking tobacco $(1.50[1.13 ; 1.98], p=0.01$, discrimination by medical staff $(1.53[1.22 ; 2.29], \quad p=0.04)$ or family $(2.48[1.75 ; 3.52], p<0.001)$, major depressive episodes $(1.46[1.02 ; 2.09], p=0.04)$, past or current drug injection $(1.54[1.03 ; 2.30], p=0.04)$, and younger age $(0.98[0.97 ; 1.00], \quad p=0.03)$. Healthcare renunciation was also negatively associated with HIV diagnosis after 1996 (1996-2002: 0.64[0.46; 0.90], $\mathrm{p}=0.01$; $\geq 2003$ : $0.56[0.40 ; 0.77], p=0.001$ ). 
Conclusions: In spite of universal health insurance in France, barrier- and refusal-renunciation of healthcare by PLHIV remains frequent. Poor psychosocial outcomes and discrimination by families and healthcare providers compound the negative effect of social insecurity on healthcare seeking in this population. To ensure optimal medical care, strategies are needed to prevent discrimination against PLHIV in healthcare services. Special attention must be provided to patients experiencing social insecurity.

Running head: Renunciation of healthcare and associated determinants among French PLHIV

\section{Introduction}

HIV-positive individuals generally have a lower socioeconomic status than the general population [13]. Social insecurity and poverty are associated with reduced levels of health monitoring in the general population [4] and among people living with HIV (PLHIV) [5]. Furthermore, people with low socioeconomic status are more likely to renounce HIV therapy in both low-income [6,7] and highincome countries [8]. In some PLHIV subgroups in developed countries, despite few financial barriers to healthcare, retention in healthcare is low [9]. Social isolation is a further risk factor for low retention to HIV multi-therapy $[5,6,10]$. Stigma and discrimination against PLHIV are additional reasons why this population seeks healthcare less often. More specifically, stigmatization by families, social networks and healthcare providers, is a risk factor for abandoning or discontinuing ART and for non-adherence [6,10-14], especially among those with a low socioeconomic status [14].

The French healthcare system has been based based on universality and solidarity since the post-was period [15]. In 2000, the creation of a specific system of access to care for the poorest people in France the "CMU" (universal health coverage) accentuated further this redistribution process, with now access at the same time to public insurance (with no conditions other than residence) and free complementary health insurance. With out-of-pocket health expenditures averaging at only $8 \%$ ( $4 \%$ in the three lowest income deciles), the French social health system is one of the most beneficial [16].

Despite this, socioeconomic inequalities in healthcare access and use persist, with $15 \%$ of the general French population reporting healthcare renunciation for financial reasons. Most of these come from disadvantaged groups [4]. Although access to care and treatment for chronic diseases, including HIV, is free in France, the HIV-infected population still suffer from discrimination, this serophobia often intertwining with sexism, racism and homophobia $[17,18]$.

The objective of the present article was to estimate the frequency of renunciation of healthcare for financial reasons among PLHIV, including healthcare unrelated to HIV, and to characterize the associated economic and psychosocial risk factors, in a context where access to care and HIV therapy are fully covered by the French healthcare system. 


\section{Methods}

\section{Design, settings and ethics}

The cross-sectional ANRS-VESPA2 survey, conducted between April 2011 and January 2012, collected information about the living conditions of PLHIV followed up in French hospitals.

A nationally representative sample of 3022 adult PLHIV were recruited in 73 French hospital departments delivering HIV care (eligibility criteria: age $\geq 18$ years, diagnosis of HIV $\geq 6$ months, residence in France $\geq 6$ months). A detailed description of the survey methodology can be found elsewhere [19].

Independent trained interviewers administered a face-to-face questionnaire to patients, in order to collect data about their socio-demographic, socioeconomic and clinical characteristics, as well as several aspects of their lives with HIV. Medical staff completed a short questionnaire about patients' health status, HIV history, and co-morbidities.

The ANRS-VESPA2 survey met the ethical requirements of the French National Commission for Computing and Liberties (approval number DR-2010-368) and received approval from the French Advisory Committee on Information Processing in Material Research in the Field of Health. All the participants provided written informed consent.

\section{Variables}

\section{Outcome: Renunciation of care}

A dichotomous variable was constructed according to a yes/no response to the question "Have you renounced healthcare for financial reasons in the past 12 months?"

\section{Explanatory variables}

A four-category socioepidemiologic variable classified participants according to their HIV transmission group as follows: men who have sex with men (MSM - self-identified as homosexual, bisexual or heterosexual men reporting at least one male sexual partner during the previous 12 months), former or active injecting drug users (IDU), Sub-Saharan African immigrants (migrants), and other heterosexual PLHIV (other) [19,20].

The EPICES score was used as a reference [21] and adapted to construct the social insecurity variable (socioeconomic and social isolation indicators) using variables available in the ANRS-VESPA2 database. The following variables were present in both the EPICES score and the ANRS-VESPA2 database: living in a couple (yes/no); owner of his/her house or flat (yes/no); having someone to rely on for material support apart from stable partner (yes/no); able to afford at least one week of holidays per year (yes/no). The following variables in the ANRS VESPA2 database were similar to some EPICES score variables: i) financial difficulties (yes/no); and ii) in contact with close family during the previous two weeks (yes/no). Some other ANRS VESPA2 variables, absent from the EPICES score, were considered as indicators of social insecurity: minimum social income (yes/no); 
recipient of universal health insurance (yes/no); having someone to rely on for moral support (yes/no); able to afford to host friends at least once a month (yes/no); able to offer gifts to family or friends at least once a year (yes/no); feeling alone (yes/no). Multiple correspondence analysis (MCA) using all the above-mentioned variables indicated the presence of two levels of social insecurity (high/low) (see Figure in supplementary material), with the position of respondent coordinates on the first dimension of MCA (which explained $91 \%$ of inertia). A description of social insecurity levels according to the variables used is available in the Table in the supplementary material.

The following variables were examined as potential correlates of renunciation of care: i) Demographic and socioeconomic characteristics: age (continuous), gender, socioepidemiologic group, education level (primary school diploma / high-school attendance but no diploma / high-school diploma and higher), social insecurity (high/low), having at least one child (yes/no), having a steady sexual partner (yes/no); ii) Substance use: current tobacco smoking (yes/no), drugs consumption (yes/no, except cannabis and poppers); iii) Experience of discrimination in the previous 24 months by medical staff (yes/no), by family (yes/no); iv) Clinical characteristics: diagnosed major depressive episode(s) (yes/no), using the World Health Organization (WHO) composite international diagnostic interview short-form (CIDI-SF) [22]), time of HIV diagnosis (before 1996, 1996-2002, 2003 and after), undetectable viral load (yes/no), CD4 cell count $/ \mathrm{mm}^{3}(<200,200-350,350-500,>500)$, combined variable of undetectable viral load and CD4 > 500 (yes/no), history of AIDS-defining event (yes/no), hepatitis $C$ diagnosis (yes/no), high blood pressure diagnosis (yes/no).

\section{Study group}

PLHIV enrolled in the ANRS-VESPA2 study with available data on renunciation of care were included in the study sample for statistical analysis $(n=3020)$.

\section{Statistical analysis}

We performed univariate and multivariate analyses using logistic regression to identify the main characteristics of PLHIV independently associated with renunciation of care compared with no renunciation of care.

Data were weighted and calibrated to be representative of the population of PLHV followed up in French hospitals in 2011. The weighting procedure accounted for the sampling technique and the heterogeneous rates of both non-participation in the survey and non-response by participants to the questionnaire [19]. All analyses were performed on weighted and calibrated data using Stata/SE

12.1 software for Windows (StataCorp LP, USA).

\section{Results}

\section{Characteristics of the study population}

Of the 3022 people included in ANRS-VESPA2, 3020 were included in the present study, as two participants had missing data on renunciation of care. Table 1 shows the characteristics of the study 
population. MSM represented the main socio-epidemiological group (39\%) and 33\% were women. Mean age was 47 years. A large proportion of those included had a high level of social insecurity (42\%). Half of the participants had at least one child, and $62 \%$ had a steady sexual partner. Eight percent and $11 \%$, respectively, experienced discrimination from medical staff and family during the 24 months prior to the survey.

\section{Frequency of healthcare renunciation}

Seventeen percent (95\% confidence interval [15\%-19\%]) of the PLHIV participating in the study declared renunciation of care during the 12 months preceding the survey.

\section{Characteristics of participants who renounced healthcare compared with others}

Comparing PLHIV who renounced healthcare with those who did not, the proportion of MSM was lower $(29 \%$ vs. $41 \%)$, but the proportion of IDU was higher ( $23 \%$ vs. $9 \%)$. Nineteen percent had a high- school diploma (vs. 32\%), and almost twice as many had a high level of social insecurity $(70 \%$ vs. $36 \%$ ). Fifty-nine percent had at least one child $45 \%$ did not have a steady sexual partner, and $52 \%$ were current smokers (vs. 50\%, 36\% and 35\%, respectively). Furthermore, $16 \%$ and $25 \%$, respectively, had been discriminated against by medical staff and family (vs. $7 \%$ and $8 \%$ ). The prevalence of major depressive episodes in those who renounced healthcare was $17 \%$ (vs. $10 \%$ ). Fifty percent were diagnosed with HIV before 1996 (vs. 39\%). Thirty-eight percent had both an undetectable viral load and a CD4 >500 (vs. 45\%). Finally, $21 \%$ had chronic hepatitis C (vs. $10 \%)$.

\section{Factors associated with renunciation of care}

The final multivariate model (Table 1) showed that the following factors were significantly associated with renunciation of healthcare: a high level of social insecurity (aOR[95\% $\mathrm{Cl}] 3.44[2.54 ; 4.65] \mathrm{p}<0.001)$, having at least one child $(1.52[1.10 ; 2.10], p=0.01)$, smoking tobacco $(1.50[1.13 ; 1.98], p=0.01)$, being an IDU (1.54[1.003;2.30], $\mathrm{p}=0.04)$, discrimination by medical staff $(1.53[1.22 ; 2.29], p=0.04)$, discrimination by family $(2.48[1.75 ; 3.52) \mathrm{p}<0.001]$ and major depressive episodes $(1.46[1.02 ; 2.09]$, $\mathrm{p}=0.04$ ). The risk of renunciation of healthcare was significantly lower among participants who had been diagnosed with HIV after 1996 (1996-2002: 0.64[0.46; 0.90], $p=0.01 ; \geq 2003$ : 0.56[0.40;0.77], $\mathrm{p}=0.001$ ). We found a trend towards a significant decrease in renunciation of healthcare per one year increase in age $(0.98[0.97 ; 1.00], p=0.03)$.

The following sociodemographic and socioeconomic factors were significantly associated with renunciation of care only in the univariate analysis (Table 1): women were significantly more likely to renounce care than men $(\mathrm{OR}[95 \% \mathrm{Cl}] 1.54[1.21 ; 1.96], \mathrm{p}=0.001)$. MSM $(0.75[0.57 ; 1.00], \mathrm{p}=0.05)$ were less likely to renounce care than other PLHIV groups. Having a high-school diploma was significantly associated with a lower risk of renunciation of healthcare than having only primary school education $(0.42[0.30 ; 0.60] p<0.001)$. The risk of renunciation of healthcare was lower among PLHIV who had a steady sexual partner (0.71[0.56;0.89], $\mathrm{p}=0.004)$. Higher CD4 counts (i.e., >200) (CD4 200-350: 0.48[0.27;0.87], $p=0.02$; CD4 350-500: 0.47[0.27;0.83], $p=0.01$; CD4 >500: 0.47[0.29;0.76], $p=0.003$ ) were significantly associated with renunciation of healthcare in the univariate model only. PLHIV who 
had both an undetectable viral load and a CD4 count $>500$ were significantly less likely to renounce healthcare $(0.46[0.60 ; 0.96], p=0.02)$. Renunciation of healthcare was significantly more frequent among participants affected by hepatitis $\mathrm{C}$ comorbidity $(2.28[0.55 ; 1.05], \mathrm{p}<0.001)$.

\section{Discussion}

In the present analysis, almost one HIV positive individual in five declared renunciation of healthcare for financial reasons, which is a worrying finding, but comparable with figures for the French general population [4]. Not surprisingly, this was associated with elevated social insecurity, a variable that takes into account low socioeconomic status. The link between poor socioeconomic status and renunciation of healthcare has been consistently shown in PLHIV in both low-income [7] and highincome countries [10].

Recent socio-anthropological research conducted in the French general population showed that healthcare renunciation takes two forms [23]: "barrier-renunciation" and "refusal-renunciation". The first is related to constraints, mostly financial in nature. When considering barrier-renunciation, our results suggest that even in a country which offers universal health insurance and widespread and free access to HIV care and treatment, economic obstacles persist for disadvantaged populations such as PLHIV, with social insecurity highly contributing to healthcare renunciation. Although the question asked in the current study was "have you renounced healthcare for financial reasons in the past 12 months?", results showed that the renunciation of healthcare was compounded by other factors. The second form of renunciation of healthcare, "refusal-renunciation" may be related to a perception of medicine as unnecessary, in some cases because of poor psychosocial outcomes such as lack of 'self-concern' [23]. In the present study, PLHIV who suffered from a major depressive episode were at greater risk of healthcare renunciation. This is consistent with previous findings highlighting associations between depression and renunciation in the general population [24-26] and with renunciation of HIV-specific care $[6,27,28]$. In our study, depression was also related to poor socioeconomic outcomes such as unemployment and material deprivation (something which has been reported in the literature), and to discrimination [29]. Refusal-renunciation may also be an expression of autonomy with regard to medicine, sometimes arising from discrimination by healthcare providers [23]. In our study, almost one PLHIV in ten reported this. A similar association was reported in poor populations in French overseas areas [30] and in US PLHIV [5]. Other authors have reported that discrimination, expressed as outright or disguised refusal or discriminatory remarks to PLHIV seeking dental and gynecological care, is worryingly frequent in France [31]. The current study did not collect any specific details about the type of discrimination participants experienced from healthcare providers. However, for the general population living with social insecurity, the literature highlights that some providers illegally refuse to deliver medical care because the applicant is only covered by universal health insurance (i.e., does not have the financial means for private out-of-pocket medical expenses) [23]. Poor doctor-patient relationships are also highlighted in the literature, where some physicians decide not to explain or discuss related issues with the patient, as they assume the latter will not understand anything [23]. Discrimination reinforces low self-esteem, negative health behaviors 
and defiance, especially in poor populations, and therefore contributes to the renunciation of healthcare. However, PLHIV participating in the ANRS-VESPA2 study were still actively included in HIV follow-up so they did not renounce all kind of healthcare. Indeed, while refusal-renunciation in some wealthier groups is more commonly related to the total and explicit refusal to seek conventional medicine because of legitimacy contestation, in disadvantaged groups it is more related to mistrust, or the perception of care as futile, or the fear of being labelled "sick" [23]. Determinants of refusalrenunciation do not necessarily mean a complete rupture with the healthcare system, yet they carry weight in the choices made in the face of financial constraints [23].

As previously reported elsewhere [17], in the ANRS VESPA2 survey, the main perceived reason for discrimination by healthcare providers was the fact that patients were HIV positive, reported by $7.2 \%$ of the study population. Worryingly, serophobia is a further criterion for discrimination against PLHIV already facing inequalities in healthcare arising from social insecurity. Financial difficulties and patient-perceived experience of rejection behaviors by medical staff were also independently associated with impaired physical and mental quality of life in the ANRS-VESPA2 survey [20].

Perceived discrimination by one's family, mainly attributed to the fact that they were HIV positive and, to a lesser degree, to sexual orientation, reported by $6.2 \%$ and $4.1 \%$ of the study population, respectively [17], was also a risk factor for renouncing healthcare. There is abundant data in the literature showing the negative impact of familial and social discrimination experienced by PLHIV on ART adherence [11,32]. Unfortunately, this discrimination is often the inadvertent consequence of the PLHIV's decision to share his/her status in order to overcome social isolation $[32,33]$. The results in this study suggest that social isolation and familial discrimination discourage PLHIV from seeking healthcare.

In the present study, IDU were more likely to renounce care. Previous research identified discrimination of HIV-infected IDU by healthcare workers as a risk factor for negative health behaviors in France [34], and as a barrier to healthcare worldwide [35-37]. Being an IDU and experiencing discrimination in healthcare services were independent risk factors for renunciation of healthcare in our study, which might indicate riskier individual health behaviors among IDU, as well as among tobacco smokers. In many settings, discrimination and stigma of PHLIV is gender-based as women are more frequently blamed for supposed promiscuity. Accordingly, women with HIV may be more discouraged from seeking healthcare $[38,39]$. This situation may be aggravated by the use of narcotics in HIV-infected women, especially in relation to pregnancy and motherhood [35]. These elements may explain why female gender was a risk factor for renunciation of healthcare in our univariate model, but unlike IDU and discrimination, disappeared in the multivariate analysis.

Diagnosis before 1996 (i.e., pre-HAART) and younger age were also risk factors for healthcare renunciation in the study population. This finding is in line with observations among PLHIV in French overseas areas where younger age and follow-up initiation before the advent of highly active antiretroviral therapy were risk factors for interrupting HIV follow-up, possibly because of higher instability, serostatus denial and fear of discrimination among young people, and better understanding 
of the benefits of HIV follow-up, together with availability of HAART in PLHIV more recently diagnosed [40]).

In the current study, having at least one child was a risk factor for renunciation of healthcare, possibly because of financial or practical reasons related to raising children. Having children may force the individual to prioritize primary needs' expenses over health expenses or to privilege child healthcare over his/her own healthcare, as a coping strategy in the face of social insecurity [5,7]. The The renunciation of healthcare benefits for children by low-income mothers has been observed in other high-income countries [41]. In France, being a single parent is an additional risk factor for social insecurity [42], and healthcare renunciation is suspected to be more likely for people who decide to have children [43].

\section{Strengths and Limitations of the study}

One of the study's limitations is that the wording of the question about renunciation of healthcare used in the ANRS VESPA2 survey - which only specified renunciation for financial reasons - led to a possible overestimation of the proportion of the general population renouncing healthcare for financial reasons [44]. However, several non-economic independent risk factors were identified in the PLHIV study population. Moreover, the risk factors associated with renunciation of healthcare were similar to those highlighted in the French general population [4].

The study did not include PLHIV not attending HIV services, in which healthcare renunciation is assumed to be more important. Therefore, the study is not representative of all adult PLHIV in France. However, the study population is representative of PLHIV attending French hospital departments delivering HIV care. The fact that we explored a multitude of factors associated with healthcare renunciation is a major strength of the study.

\section{Recommendations}

Despite the large progress made in the last 15 years with respect to decreasing discrimination against people infected with HIV, it is still frequent and efforts to reduce it further must be continued [45]. The present results highlight that discrimination of PHLIV by healthcare workers persisted in 2011 and that it has negative consequences on PLHIV seeking healthcare.

The guidelines to improve HIV prevention and therapy of WHO in 2004 did not include specific recommendations to prevent discrimination perpetrated by healthcare providers [46]. However in 2016, the consolidated guidelines of WHO highlighted the importance of changing healthcare providers' behaviors using appropriate resources and training, in order to reduce discrimination against HIV-infected people, especially homosexuals, transsexuals, sex workers and drug users [47]. Beyrer et al. extended this recommendation to all non-medical staff working in healthcare structures, such as security guards and intake clerks, who can be agents of stigma and discrimination to at-risk populations such as MSM and IDU [37]. More research in interventions to decrease HIV-associated stigma and discrimination has also been recommended [25]. 


\section{Conclusion}

Besides the considerable long-term challenge of reducing social and economic inequalities in the general society, in the short term, discrimination and social stigma related to serophobia can and should be addressed in order to encourage more PLHIV to seek healthcare.

\section{Acknowledgements}

The authors thank all the PLHIV who agreed to participate in the ANRS-VESPA2 Study, all the members of the various medical staff in the participating hospitals, and the community-based organizations AIDES and Act-Up Paris. Our thanks also to IPSOS for their participation in data collection and Clinsearch for their help with coordination. Finally, our thanks to Jude Sweeney for revising and editing the English version of the manuscript.

The ANRS-VESPA2 survey was sponsored and funded by the French National Agency for Research on Aids and Viral Hepatitis (ANRS).

\section{Disclosure statement}

The authors declare no conflict of interest

\section{References}

1. Boyer V, Vilotitch A, Panjo H, et al. Heterosexual practices of women and men living with HIV attending hospital outpatient services (ANRS-VESPA2 survey): a French comparative study with the general population (CSF survey). AIDS Care 2016; 28:1345-1354.

2. Yin Z, Brown AE, Hughes G, Nardone A, Gill ON, Delpech VC \& contributors. HIV in the United Kingdom 2014 Report: data to end 2013. Public Health England, London; 2014 nov.

3. Economically Disadvantaged | HIV by Group | HIV/AIDS | CDC [Internet]. [cité 1 juin 2017]. Disponible sur: https://www.cdc.gov/hiv/group/poverty.html

4. Després $C$, Dourgnon $P$, Fantin $R$, Jusot $F$. Le renoncement aux soins pour raisons financières: une approche économétrique. Irdes Quest D'économie Santé [Internet]. 2011 [cité 3 mai 2017];170. Disponible sur: http://archive.cfecgc.org/e_upload/pdf/irdesnov2011.pdf

5. Mehta S, Moore RD, Graham NM. Potential factors affecting adherence with HIV therapy. AIDS 1997; 11:1665-1670.

6. Marega A, Pires P, Samuel J. Antiretroviral treatments abandon determinants in HIV positive patients, Chiúre, Mozambique, 2015. 2017 [cité 3 mai 2017]; Disponible sur:

http://www.unilurio.ac.mz/unilurio/docs/publicacoes/2017/ATADHIV+P\%20Chiure\%20Mozambique\%2 0lJR\%20Article.pdf

7. Geng EH, Nash D, Kambugu A, et al. Retention in care among HIV-infected patients in resource-limited settings: emerging insights and new directions. Curr HIV/AIDS Rep 2010; 7:234-244.

8. Burch LS, Smith CJ, Phillips AN, Johnson MA, Lampe FC. Socioeconomic status and response to antiretroviral therapy in high-income countries: a literature review. AIDS 2016; 30:11471162.

9. Giordano TP, Gifford AL, White AC, et al. Retention in care: a challenge to survival with HIV infection. Clin Infect Dis 2007; 44:1493-1499.

10. Kalichman SC, Grebler T. Stress and poverty predictors of treatment adherence among people with low-literacy living with HIV/AIDS. Psychosom Med 2010; 72:810.

11. Sayles JN, Wong MD, Kinsler JJ, Martins D, Cunningham WE. The association of stigma with self-reported access to medical care and antiretroviral therapy adherence in persons living with HIV/AIDS. J Gen Intern Med 2009; 24:1101.

12. Wohl AR, Galvan FH, Myers HF, et al. Do social support, stress, disclosure and stigma influence retention in HIV care for Latino and African American men who have sex with men and women? AIDS Behav 2011; 15:1098-1110. 
13. Schuster MA, Collins R, Cunningham WE, et al. Perceived discrimination in clinical care in a nationally representative sample of HIV-infected adults receiving health care. J Gen Intern Med 2005; 20:807-813.

14. Mateveke K, Singh B, Chingono A, Sibanda E, Machingura I. Is socio-economic status a determinant of HIV-related stigma attitudes in Zimbabwe? Findings from Project Accept. J Public Health Afr [Internet]. 2016 [cité 3 mai 2017];7 [1]. Disponible sur: https://www.ncbi.nlm.nih.gov/pmc/articles/PMC5349255/

15. Saltman R, Rico A, Boerma W. Social health insurance systems in western Europe [Internet]. McGraw-Hill Education (UK); 2004 [cité 15 sept 2017]. Disponible sur:

https://books.google.fr/books?hl=fr\&lr=\&id=dQpewBbXn8oC\&oi=fnd\&pg=PP1\&dq=social+health+insur ance+western+europe\&ots=9lh12isWpQ\&sig=z-C0VFov7UOyET-W5C7zxFIQ96I

16. Nay O, Béjean S, Benamouzig D, Bergeron H, Castel P, Ventelou B. Achieving universal health coverage in France: policy reforms and the challenge of inequalities. Lancet 2016; 387:22362249.

17. Marsicano E, Dray-Spira R, Lert F, et al. Multiple discriminations experienced by people living with HIV in France: results from the ANRS-Vespa2 study. AIDS Care 2014; 26 Suppl 1:S97-S106.

18. (France) A nationale de recherches sur le sida, SIDA FC national du, santé FM des affaires sociales et de la, Morlat P. Prise en charge médicale des personnes vivant avec le VIH: rapport 2013 [pour le] Ministère des affaires sociales et de la santé: recommandations du groupe d'experts. la Documentation française;

19. Dray-Spira R, Spire B, Lert F. Méthodologie générale de l'enquête ANRS-VESPA2. Bull Épidémiologique Hebd. 2013 [26,27]:321-324.

20. Douab T, Marcellin F, Vilotitch A, Protopopescu C, Préau M, Suzan-Monti M, et al. Health-related quality of life of people living with HIV followed up in hospitals in France: comparing trends and correlates between 2003 and 2011 (ANRS-VESPA and VESPA2 national surveys). AIDS Care. 2014;26(sup1):S29-S40.

21. Sass C, Moulin J-J, Guéguen R, et al. Le score Epices: un score individuel de précarité. Construction du score et mesure des relations avec des données de santé, dans une population de 197389 personnes. Bull Épidémiologique Hebd. 2006; 14:93-96.

22. Kessler RC, Andrews G, Mroczek D, Ustun B, Wittchen H-U. The World Health Organization composite international diagnostic interview short-form (CIDI-SF). Int J Methods Psychiatr Res 1998; 7:171-185.

23. Desprès $C$, Dourgnon $P$, Fantin $R$, Jusot $F$. Le renoncement aux soins: une approche socioanthropologique. Quest Déconomie Santé. 2011;(169):1-7.

24. Baggio S, Iglesias K, Fernex A. Healthcare renunciation among young adults in French higher education: A population-based study. Prev Med 2017; 99:37-42.

25. Thompson MA, Mugavero MJ, Amico KR, Cargill VA, Chang LW, Gross R, et al. Guidelines for improving entry into and retention in care and antiretroviral adherence for persons with HIV: evidencebased recommendations from an International Association of Physicians in AIDS Care panel. Ann Intern Med. 5 juin 2012;156 [11]:817-33, W-284, W-285, W-286, W-287, W-288, W-289, W-290, W291, W-292, W-293, W-294.

26. Litwin $\mathrm{H}$, Sapir EV. Forgone health care due to cost among older adults in European countries and in Israel. Eur J Ageing 2009; 6:167-176.

27. Mugavero MJ. Improving engagement in HIV care: what can we do? Top HIV Med Publ Int AIDS Soc USA. 2008; 16:156-161.

28. Rao D, Kekwaletswe TC, Hosek S, Martinez J, Rodriguez F. Stigma and social barriers to medication adherence with urban youth living with HIV. AIDS Care 2007; 19:28-33.

29. Feuillet $\mathrm{P}$, Lert F, Tron L, et al. Prevalence of and factors associated with depression among people living with HIV in France. HIV Med 2016; 14.

30. Valmy L, Gontier B, Parriault MC, et al. Prevalence and predictive factors for renouncing medical care in poor populations of Cayenne, French Guiana. BMC Health Serv Res 2016; 16:34. 
31. Douay C, Toullier A, Benayoun S, Castro DR, Chauvin P. Refusal to provide health care to people with HIV in France. Lancet 2016; 387:1508-1509.

32. Ware NC, Wyatt MA, Tugenberg T. Social relationships, stigma and adherence to antiretroviral therapy for HIV/AIDS. AIDS Care 2006; 18:904-910.

33. Ghadi V, Serbandini N. Les femmes migrantes, le VIH et la parole. Plein Droit. 2010 [3]:24-27.

34. Peretti-Watel P, Spire B, Obadia Y, Moatti J-P, Group V. others. Discrimination against HIVinfected people and the spread of HIV: some evidence from France. PLoS One 2007; 2:e411.

35. Pinkham S, Malinowska-Sempruch K. Women, harm reduction and HIV. Reprod Health Matters 2008; 16:168-181.

36. Wolfe D, Carrieri MP, Shepard D. Treatment and care for injecting drug users with HIV infection: a review of barriers and ways forward. Lancet Lond Engl. 2010; 376:355-366.

37. Beyrer C, Baral S, Kerrigan D, El-Bassel N, Bekker L-G, Celentano DD. Expanding the space: inclusion of most-at-risk populations in HIV prevention, treatment, and care services. J Acquir Immune Defic Syndr 1999. 2011;57(Suppl 2):S96.

38. The Gender Aspects of the HIV/AIDS Pandemic [Internet]. [cité 31 mai 2017]. Disponible sur: http://www.un.org/womenwatch/daw/csw/hivaids/matlinspence.html

39. Organization WH. others. Consolidated guideline on sexual and reproductive health and rights of women living with HIV. 2017 [cité 31 mai 2017]; Disponible sur: http://apps.who.int/iris/bitstream/10665/254885/1/9789241549998-eng.pdf

40. Nacher M, El Guedj M, Vaz T, Nasser V, Randrianjohany A, Alvarez F, et al. Risk factors for follow-up interruption of HIV patients in French Guiana. Am J Trop Med Hyg 2006; 74:915-917.

41. Simmons LA, Huddleston-Casas CA, Morgan KA, Feldman D. Mixed methods study of management of health conditions in rural low-income families: implications for health care policy in the USA. Rural Remote Health 2012; 12:1879.

42. Duhamel É, Joyeux H, de France F. Femmes et précarité. Études Cons Économique Soc Environnemental Conceil Économique Soc Environnemental [Internet]. 2013 [cité 31 mai 2017];130. Disponible sur: http://www.lecese.fr/sites/default/files/pdf/Fiches/2013/FI09_femmes_precarite.pdf

43. Ancelot L, Bonnal L, Depret $\mathrm{M}-\mathrm{H}$. Déclarations de renoncement aux soins et non-recours aux services de santé: mesures comparatives et déterminants. [cité 26 mai 2017]; Disponible sur: http://www.ces-asso.org/sites/default/files/Ancelot_Bonnal_Depret.pdf

44. Legal R, Vicard A. Renoncement aux soins pour raisons financières: le taux de renoncement aux soins pour raisons financières est très sensible à la formulation des questions. Doss Solidar Santé. 2015;66.

45. Stangl AL, Lloyd JK, Brady LM, Holland CE, Baral S. A systematic review of interventions to reduce HIV-related stigma and discrimination from 2002 to 2013: how far have we come? J Int AIDS Soc [Internet]. 2013 [cité 30 mai 2017];16 [3]. Disponible sur:

http://www.jiasociety.org/index.php/jias/article/view/18734

46. WHO. I Chronic HIV care with ARV therapy and prevention [Internet]. WHO. [cité 30 mai 2017]. Disponible sur: http://www.who.int/hiv/pub/imai/primary_arv/en/

47. Organization WH. others. Consolidated guidelines on HIV prevention, diagnosis, treatment and care for key populations-2016 update. 2016 [cité 30 mai 2017]; Disponible sur: http://apps.who.int/iris/bitstream/10665/246200/1/9789241511124-eng.pdf 
Table 1. Factors associated with renunciation of healthcare, ANRS-VESPA 2 survey, $n=3020$

\begin{tabular}{|c|c|c|c|c|c|c|c|c|}
\hline & \multirow{2}{*}{$\begin{array}{l}\text { Total }(\mathrm{n}=3020) \\
\mathrm{N}(\%) \text { or mean } \\
\text { (SE) }\end{array}$} & \multicolumn{2}{|c|}{ Renunciation of healthcare $a, b$} & \multirow{2}{*}{$\begin{array}{l}\text { Proportion of } \\
\text { renunciation of } \\
\text { healthcare } \\
\text { among groups } \\
(\%)\end{array}$} & \multicolumn{2}{|c|}{ Univariate analysis $(\mathrm{n}=3020)$} & \multicolumn{2}{|c|}{ Multivariate analysis $\left(n=2976^{c}\right)$} \\
\hline & & $\begin{array}{c}\text { No } \\
N(\%) \text { or mean } \\
(\mathrm{SE}) \\
\end{array}$ & $\begin{array}{c}\text { Yes } \\
\mathrm{N}(\%) \text { or mean } \\
(\mathrm{SE}) \\
\end{array}$ & & OR [95\%Cl] & $\mathrm{p}$-value & aOR [95\%Cl] & $p$-value \\
\hline All & $3020(100)$ & $2512(100)$ & $508(100)$ & 17.0 & & & & \\
\hline \multicolumn{9}{|l|}{$\begin{array}{l}\text { Demographics and } \\
\text { socioeconomics }\end{array}$} \\
\hline Age (year) & $47.4(0.25)^{*}$ & $47.7(0.28)^{*}$ & $46.1(0.51)^{\star}$ & & $0.99[0.98 ; 1.00]^{\mathrm{e}}$ & 0.01 & $0.98[0.97 ; 1.00]^{\mathrm{e}}$ & 0.03 \\
\hline \multicolumn{9}{|l|}{ Gender } \\
\hline Male & $2076(66.7)$ & 1763 (68.4) & $313(58.4)$ & 14.9 & Ref & & & \\
\hline Female & $944(33.3)$ & $749(31.6)$ & $195(41.6)$ & 21.2 & $1.54[1.21 ; 1.96]$ & 0.001 & & \\
\hline \multicolumn{9}{|l|}{ Socioepidemiologic group } \\
\hline MSM & $1336(39.1)$ & $1154(41.1)$ & $182(29.1)$ & 12.6 & $0.75[0.57 ; 1.00]$ & 0.05 & $1.03[0.73 ; 1.46]$ & 0.86 \\
\hline IDU & $323(11.0)$ & $216(8.5)$ & $107(23.3)$ & 36.0 & $2.93[2.04 ; 4.20]$ & $<0.001$ & $1.54[1.03 ; 2.30]$ & 0.04 \\
\hline Migrant & $601(23.7)$ & $513(23.9)$ & $88(22.7)$ & 16.3 & $1.01[0.70 ; 1.46]$ & 0.95 & $0.78[0.50 ; 1.20]$ & 0.25 \\
\hline Other & 760 (26.2) & $629(26.5)$ & $131(24.9)$ & 16.1 & Ref & & Ref & \\
\hline \multicolumn{9}{|l|}{ Educational level } \\
\hline Primary School Diploma & $563(19.3)$ & $454(18.1)$ & $109(24.7)$ & 21.7 & Ref & & & \\
\hline High School -No diploma & $1575(50.5)$ & $1281(49.3)$ & $294(56.6)$ & 19.0 & $0.84[0.62 ; 1.14]$ & 0.27 & & \\
\hline High school - Diploma & $876(30.2)$ & $773(32.6)$ & $103(18.7)$ & 10.5 & $0.42[0.30 ; 0.60]$ & $<0.001$ & & \\
\hline \multicolumn{9}{|l|}{ Social Insecurity } \\
\hline Low & $1732(58.2)$ & $1580(64.1)$ & $152(29.5)$ & 8.6 & Ref & & Ref & \\
\hline High & $1288(41.8)$ & $932(35.9)$ & $356(70.5)$ & 28.6 & $4.25[3.31 ; 5.45]$ & $<0.001$ & $3.44[2.54 ; 4.65]$ & $<0.001$ \\
\hline \multicolumn{9}{|l|}{ Children } \\
\hline No & $1593(48.9)$ & $1354(50.5)$ & $239(41.1)$ & 14.2 & Ref & & Ref & \\
\hline Yes & $1427(51.1)$ & 1158 (49.5) & 269 (58.9) & 19.6 & $1.47[1.16 ; 1.86]$ & 0.002 & $1.52[1.10 ; 2.10]$ & 0.01 \\
\hline \multicolumn{9}{|l|}{ Steady sexual partner } \\
\hline No & 1187 (37.9) & $948(36.4)$ & $239(44.9)$ & 20.2 & Ref & & & \\
\hline Yes & $1807(62.1)$ & $1542(63.6)$ & $265(55.1)$ & 15.1 & $0.70[0.56 ; 0.89]$ & 0.004 & & \\
\hline \multirow{2}{*}{\multicolumn{9}{|c|}{$\begin{array}{l}\text { Substance use } \\
\text { Current tobacco smoker }\end{array}$}} \\
\hline & & & & & & & & \\
\hline No & $1783(62.4)$ & 1564 (65.4) & $219(48.0)$ & 13.0 & Ref & & Ref & \\
\hline Yes & $1236(37.6)$ & $948(34.6)$ & $288(52.0)$ & 23.5 & $2.04[1.62 ; 2.58]$ & $<0.001$ & $1.50[1.13 ; 1.98]$ & 0.01 \\
\hline
\end{tabular}




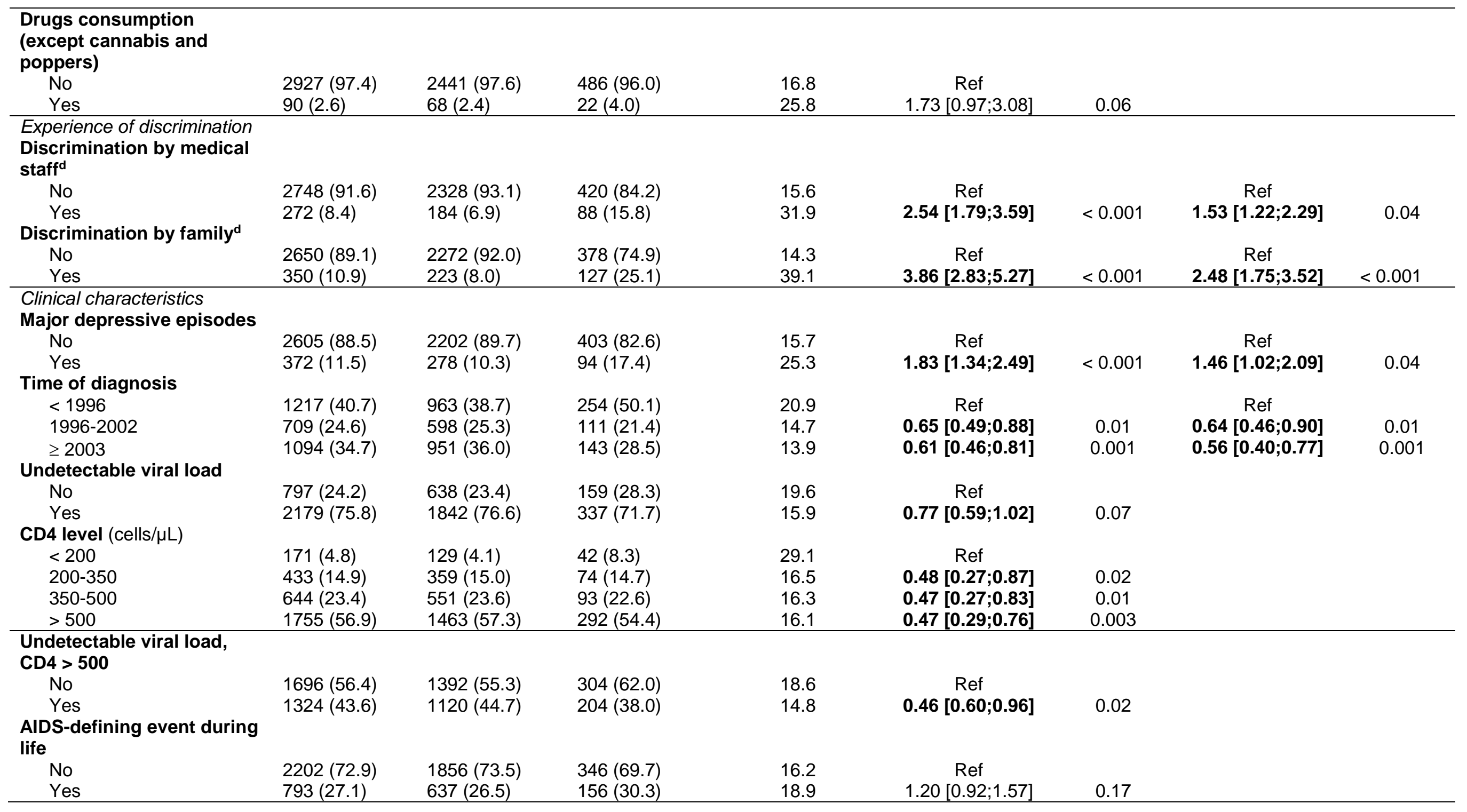




\section{Chronic hepatitis C}

No

Yes

$2611(88.1)$

364 (11.9)

$2211(89.8)$

$400(79.5)$

265 (10.2)

$99(20.5)$

Ref

High blood pressure

No

$2522(84.4)$

2084 (83.9)

$438(87.3)$ $424(15.6)$

$361(16.1) \quad 63(127)$

$14.1 \quad 0.76[0.55 ; 1.05]$

Ref

a During the 12 months prior to the survey

${ }^{b}$ A total lower than 3020 is due to missing data

c 44 missing data in explanatory variables

d During the 24 months prior to the survey

e Per one year older

$\mathrm{Cl}$ : Confidence Interval

${ }^{*}$ mean $(\mathrm{SE})$ 
Supplementary figure : Multiple correspondance analysis (MCA) to construct the social insecurity variable MCA coordinate plot

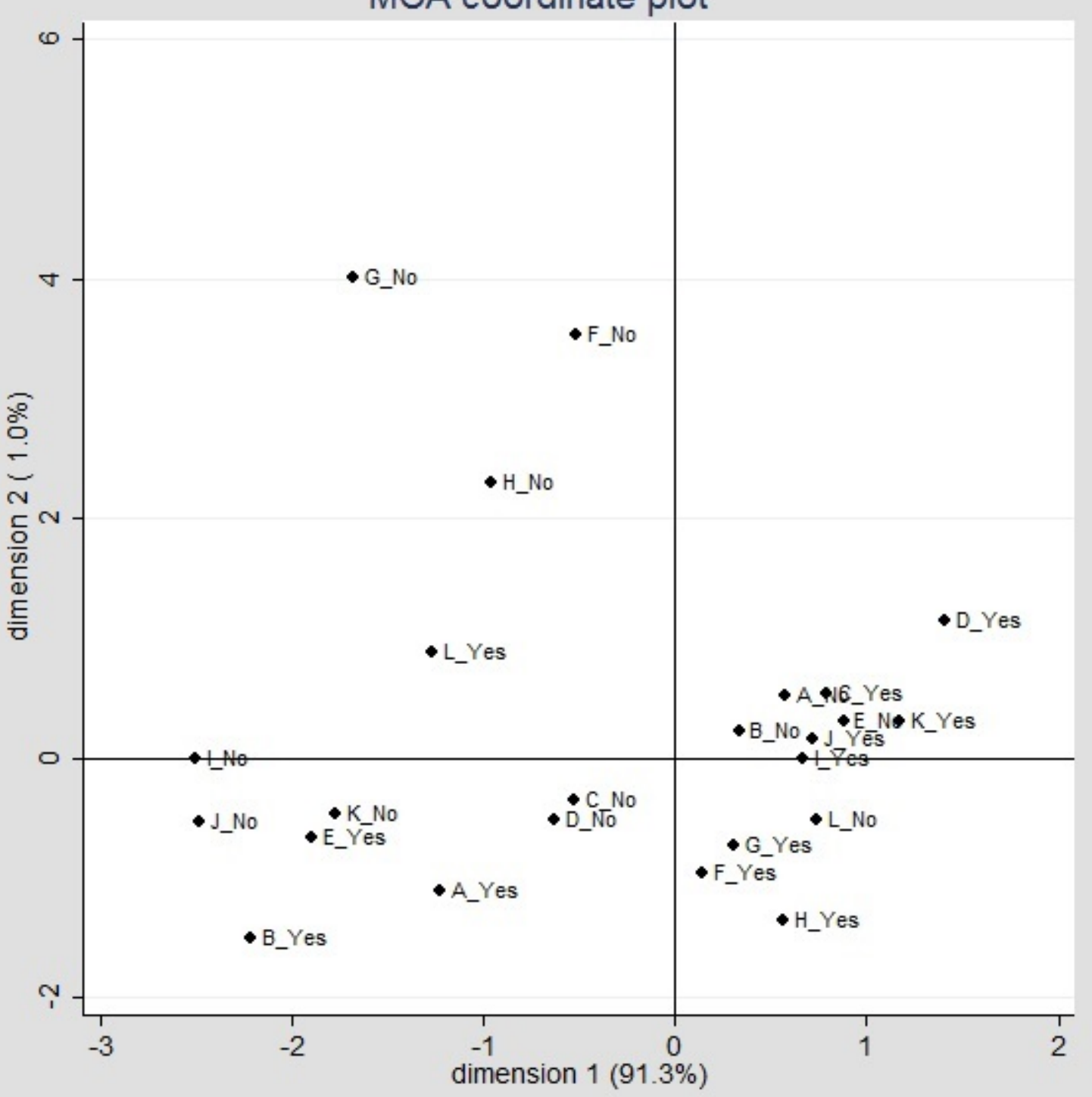

- A Recipient of minimum social income

- C Living in a couple

- E Financial difficulties

- G Having someone to rely on for moral support

- I Able to afford to host friends at least once a month

- K Able to afford at least one week of holidays per year
- B Recipient of universal health insurance

- D Owner of his/her house or flat

- F In contact with close family during the previous two weeks

- H Having someone to rely on for material support

- J Able to offer gifts to family or friends at least once a year

- L Feeling alone 
Supplementary table: Level of precariousness according to construction variables of precariousness. ANRS-VESPA 2 study, $n=3022$

\begin{tabular}{|c|c|c|c|}
\hline & $\begin{array}{l}\text { Low precariousness } \\
\text { Weighted percent (N) }\end{array}$ & $\begin{array}{l}\text { High precariousness } \\
\text { Weighted percent (N) }\end{array}$ & Total $(n=3022)^{*}$ \\
\hline \multicolumn{4}{|c|}{ Minimal social income recipient } \\
\hline No & $85.0(1434)$ & $48.9(610)$ & $69.9(2044)$ \\
\hline Yes & $15.0(282)$ & $51.1(670)$ & $30.1(952)$ \\
\hline \multicolumn{4}{|c|}{ Universal health insurance recipient } \\
\hline No & $98.1(1680)$ & $70.3(904)$ & $13.4(2584)$ \\
\hline Yes & $1.9(43)$ & $29.7(366)$ & $86.6(409)$ \\
\hline \multicolumn{4}{|c|}{ Living in a couple } \\
\hline No & $48.0(847)$ & 75.1 (979) & $59.4(1826)$ \\
\hline Yes & $52.0(885)$ & $24.9(311)$ & $40.6(1196)$ \\
\hline \multicolumn{4}{|c|}{ Owner of housing } \\
\hline No & $52.1(920)$ & $91.7(1187)$ & $68.7(2107)$ \\
\hline Yes & $47.9(812)$ & $8.3(103)$ & $31.3(915)$ \\
\hline \multicolumn{4}{|c|}{ Financial difficulties } \\
\hline No & $93.2(1604)$ & $33.7(445)$ & $68.5(2049)$ \\
\hline Yes & $6.8(127)$ & $66.3(831)$ & $31.5(958)$ \\
\hline \multicolumn{4}{|c|}{$\begin{array}{l}\text { Contacts with family (except children and } \\
\text { parents) }\end{array}$} \\
\hline No & $16.4(308)$ & 26.5 (349) & $20.6(657)$ \\
\hline Yes & $83.6(1423)$ & 73.5 (933) & $79.4(2356)$ \\
\hline \multicolumn{4}{|c|}{ Having someone to rely on for moral support } \\
\hline No & $6.7(114)$ & $30.2(371)$ & $16.5(485)$ \\
\hline Yes & $93.3(1610)$ & $69.8(906)$ & $83.5(2516)$ \\
\hline \multicolumn{4}{|c|}{$\begin{array}{l}\text { Having someone to rely on for material } \\
\text { support }\end{array}$} \\
\hline No & $26.0(434)$ & $58.5(718)$ & $39.6(1152)$ \\
\hline Yes & $74.0(1298)$ & $41.5(572)$ & $60.4(1870)$ \\
\hline \multicolumn{4}{|c|}{$\begin{array}{l}\text { Can afford to host friends at least once a } \\
\text { month }\end{array}$} \\
\hline No & $1.4(24)$ & $49.2(617)$ & $21.3(641)$ \\
\hline Yes & $98.6(1700)$ & $50.8(647)$ & $78.7(2347)$ \\
\hline \multicolumn{4}{|c|}{ Can afford to offer gifts at least once a year } \\
\hline No & $1.0(18)$ & $50.5(673)$ & $21.6(691)$ \\
\hline Yes & $99.0(1709)$ & $49.5(602)$ & $78.4(2311)$ \\
\hline \multicolumn{4}{|c|}{$\begin{array}{l}\text { Can afford at least one week of holidays per } \\
\text { year }\end{array}$} \\
\hline No & $8.2(156)$ & $83.0(1053)$ & $39.4(1209)$ \\
\hline Yes & $91.8(1567)$ & $17.0(225)$ & $60.6(1792)$ \\
\hline \multicolumn{4}{|l|}{ Feeling alone } \\
\hline No & $81.4(1383)$ & $41.3(504)$ & 64.7 (1887) \\
\hline Yes & $18.6(346)$ & 58.7 (777) & $35.3(1123)$ \\
\hline
\end{tabular}

\footnotetext{
* Total lower than 3022 due to missing data.
} 